\title{
Rancang Bangun Sistem Informasi Penerimaan Mahasiswa Baru Berbasis Web Di Sekolah Tinggi Keguruan Ilmu Pendidikan Paracendekia Nahdlatul Wathan Sumbawa
}

\author{
Muhammad Dian Fajri ${ }^{1}$,Wirentake ${ }^{2}$, M. Julkarnain ${ }^{3}$ \\ ${ }^{1)}$ Mahasiswa, Universitas Teknologi Sumbawa \\ 2),3) Dosen, Universitas Teknologi Sumbawa \\ Email:ㅁianfajri.74@gmail.com ${ }^{1)}$, wirentake@uts.ac.id ${ }^{2}$, $\underline{\text { m.julkarnain.uts.ac.id }}^{3)}$
}

\begin{abstract}
Abstrak
STKIP Paracendekia NW Sumbawa merupakan suatu lembaga pendidikan yang bergelut di bidang pendidikan bahasa inggris dan pendidikan matematika. STKIP Paracendekia NW Sumbawa setiap tahun menyelenggarakan penerimaan mahasiswa baru. Dalam menyelenggarakan penerimaan mahasiswa baru, STKIP Paracendekia NW Sumbawa masih menggunakan sistem yang manual yaitu dengan mencatat semua pendaftar menggunakan buku dan formulir pendaftran masih di simpan di dalam lemari. Hal ini menjadikan panitia penyelenggara kesulitan dalam mengelolah data yang setiap waktunya data akan berubah terus menerus. Solusi dari permasalahan yang sedang terjadi di STKIP Paracendekia NW Sumbawa adalah membangun Sistem Informasi Penerimaan Mahasiswa Baru Berbasis Web di STKIP Paracendekia NW Sumbawa. Sistem ini dikembangkan menggunakan bahasa pemrograman PHP dengan menggunakan Framework CodeIgniter dan MysSql sebagai database. Metode yang digunakan dalam membangun sistem ini adalah menggunakan metode waterfall. Sistem ini diharapkan dapat mempermudah dan mempercepat proses pengelolaan data calon mahasiswa baru.
\end{abstract}

Kata kunci : Sekolah Tinggi Keguruan Ilmu Pendidikan Paracendekia Nahdlatul Wathan Sumbawa, Sistem Informasi, Penerimaan Mahasiswa Baru, Waterfall

\section{Abstract}

STKIP Paracendekia NW Sumbawa is an educational institution that deals in English education and mathematics education. STKIP Paracendekia NW Sumbawa organizes new student admissions every year. In organizing the admission of new students, STKIP Paracendekia NW Sumbawa still uses a manual system that is by recording all registrants using books and registration forms are still stored in a cupboard. This makes it difficult for the organizing committee to manage data, which data will change from time to time. The solution to the problems that are happening at STKIP Paracendekia NW Sumbawa is to build a Web-Based New Student Admission Information System at STKIP Paracendekia NW Sumbawa. This system was developed using the PHP programming language by using the CodeIgniter and MysSql Framework as a database. The method used in building this system is to use the waterfall method. This system is expected to simplify and speed up the data management process for prospective new students.

Keywords: Teaching High School Science Education Paracendekia Nahdlatul Wathan Sumbawa, System Information, Admissions, Waterfall

\section{PENDAHULUAN}

Kebutuhan akan teknologi informasi sangat mempengaruhi atau menentukan arah perkembangan dari objek yang menggunakan teknologi tersebut, misalnya pada instansi yang telah menerapkan teknologi informasi tentunya akan lebih berkembang dibandingkan instansi yang belum menerapkan teknologi informasi. Tidak hanya pada instansi semata tetapi teknologi informasi juga telah memberikan dampak yang signifikan terhadap dunia pendidikan mulai dari sekolah dasar, sekolah menengah hingga sekolah tinggi.

Sekolah Tinggi Keguruan Ilmu Pendidikan Paracendekia Nahdlatul Wathan Sumbawa (STKIP Paracendekia NW Sumbawa) adalah sekolah tinggi yang bergelut bidang pendidikan ilmu Matematika dan Bahasa Inggris. Hal ini dibuktikan dengan meningkatnya jumlah mahasiswa baru yang mendaftar dari tahun ke tahun. Namun dalam penyelenggaraan penerimaan mahasiswa baru masih mengalami kesulitan, hal ini dikarenakan proses pendaftaran dan pendataan masih bersifat manual. Calon mahasiswa baru harus mengisi formulir pada lembaran kertas dan melengkapi berkas persyaratan dimana formulir dan berkas persyaratan tersebut disimpan dalam lemari, sehingga dikhawatirkan berkas rentan terhadap kerusakan dan rawan akan kehilangan. Selain itu dikarenakan data calon mahasiswa baru masih berbasis kertas, proses pengelolaan data oleh pihak STKIP Paracendekia NW Sumbawa menjadi tidak efektif dan efisien. 
Oleh karena itu pihak STKIP Paracendekia NW Sumbawa membutuhkan sebuah sistem informasi pendaftaran mahasiswa baru berbasis web guna mempermudah proses pendaftaran oleh calon mahasiswa baru sekaligus mempermudah proses pengelolaan data oleh pihak STKIP Paracendekia NW Sumbawa.

Berdasarkan permasalahan diatas penulis akan membuat Sistem Informasi Penerimaan Mahasiswa Baru Berbasis Web Di STKIP Paracendekia NW Sumbawa. Dengan demikian, sistem informasi tersebut dapat memudahkan calon mahasiswa baru untuk melakukan proses pendaftaran tanpa harus mengambil formulir ke pihak STKIP Paracendekia NW Sumbawa serta menunjang kinerja panitia dalam menyelenggarakan penerimaan mahasiswa baru yaitu berupa sistem informasi yang bermanfaat untuk membantu panitia penyelenggara dalam mengelolah data termasuk menyimpan, memproses, mendapatkan dan menampilkan data calon mahasiswa baru sehingga pencatatan dan perekapan data calon mahasiswa baru lebih mudah karena data-data tersebut telah tersimpan secara terstruktur di dalam database.

\section{TINJAUAN PUSTAKA}

Setelah melakukan observasi terhadap beberapa penelitian lainnya terkait dengan penelitian yang penulis lakukan, penulis menemukan keterkaitan dengan proses yang penulis lakukan.

Penelitian pertama dari skripsi (Nilna Amaliya Fajria, 2007) yang berjudul "Sistem Informasi Penerimaan Mahasiswa Baru Universitas Setia Budi Surakarta Berbasis Client/Server" yang bertujuan untuk pengembangan sistem seperti adanya database calon mahasiswa, pencetakan kartu ujian secara otomatis, dapat melayani multiuser dengan adanya ujian secara on-line, dan terintegrasinya sistem secara client/erver sehingga user akan lebih mudah dalam mengakses data.

Hasil dari penelitian tersebut menunjukkan bahwa dengan adanya sistem informasi penerimaan mahasiswa baru data-data yang dihasilkan dapat diolah sedemikian rupa sehingga dapat diorganisir dalam suatu sistem yang terkomputerisasi.

Penelitian kedua dari jurnal (Ruhul Amin, 2017) yang berjudul "Rancang Bangun Sistem Informasi Penerimaan Siswa Baru Pada SMK Budhi Warman 1 Jakarta" yang bertujuan untuk memudahkan dalam proses pendataan, pencarian data dan mengurangi kesalahan data.

Hasil dari penelitian tersebut menunjukkan bahwa dengan adanya sistem informasi penerimaan mahasiswa baru dapat membantu panitia penyelenggara dalam menyelenggarakan penerimaan mahasiswa baru.

Penelitian ketiga dari skripsi (Zea Riza Lestari, 2017) yang berjudul "Analisis Sistem Informasi Penerimaan Siswa Baru Berbasis Web Pada SMK
Negeri 5 Batam" yang bertujuan untuk mempermudah dalam membuat laporan jumlah siswa yang mendaftar dan mempermudah dalam pencarian arsip-arsip calon siswa yang telah mendaftar.

Hasil dari penelitian ini menunjukkan bahwa dengan adanya sistem informasi dalam menunjang kinerja panitia penerimaan siswa baru dalam melakukan pencarian arsip-arsip dan membuat laporan jumlah siswa baru.

\section{Landasan Teori}

\section{Pengertian Rancang Bangun}

Rancang bangun merupakan kegiatan menerjemahkan hasil analisa ke dalam bentuk paket perangkat lunak kemudian menciptakan sistem tersebut ataupun memperbaiki sistem yang sudah ada (Lestariningsih dkk, 2015). ${ }^{[3]}$.

Maka dapat disimpulkan bahwa rancang bangun merupakan suatu kegiatan untuk menerjemahkan suatu kegiatan analisa ke dalam bentuk perangkat lunak untuk memperbaiki sistem yang sudah ada dalam menolong manusia guna membantu dalam tugas tertentu.

\section{Sistem Informasi}

Sistem informasi merupakan kumpulan dari komponen- komponen yang mengumpulkan, memproses, menyimpan dan menyediakan output dari setiap informasi yang dibutuhkan dalam proses bisnis serta aplikasi yang digunakan melalui prangkat lunak, database dan bahkan proses manual yang terkait (Satzinger dkk, 2012). ${ }^{[6]}$.

Maka dapat disimpulkan bahwa sistem informasi adalah suatu kombinasi modul yang terorganisir yang berasal dari komponen- komponen yang terkait dengan hardware, software, people dan network berdasarkan seperangkat 24omputer dan menghasilkan informasi untuk mencapai tujuan.

\section{Unified Modeling Language}

Unified Modeling Language adalah bahasa standar untuk pemodelan perangkat lunak yang digunakan untuk model proses bisnis dan muncul sebagai standar umum untuk pemodelan berorientasi objek (Booch, 2005). ${ }^{[4]}$.

\section{CodeIgneter}

CodeIgniter adalah sebuah web application framework yang bersifat open source digunakan untuk membangun aplikasi php dinamis. Tujuan utama pengembangan CodeIgniter adalah untuk membantu developer untuk mengerjakan aplikasi yang lebih cepat dari pada menulis code dari awal (Ibnu Daqiqil, 2011). 


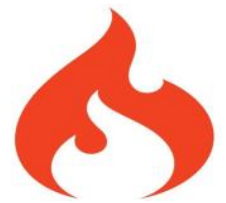

Gambar 1. Logo CodeIgniter

CodeIgniter dibangun menggunakan konsep Model-View- Controller development pattern. CodeIgniter sendiri merupakan salah satu framework tercepat dibandingkan dengan framework lainnya. Pada acara frOSCon (agustus 2008).

\section{METODE PENELITIAN}

Tahapan yang dilakukan penulis dalam mengumpulkan data untuk membuat sistem ini dapat digambarkan pada alur penelitian sebagai berikut:

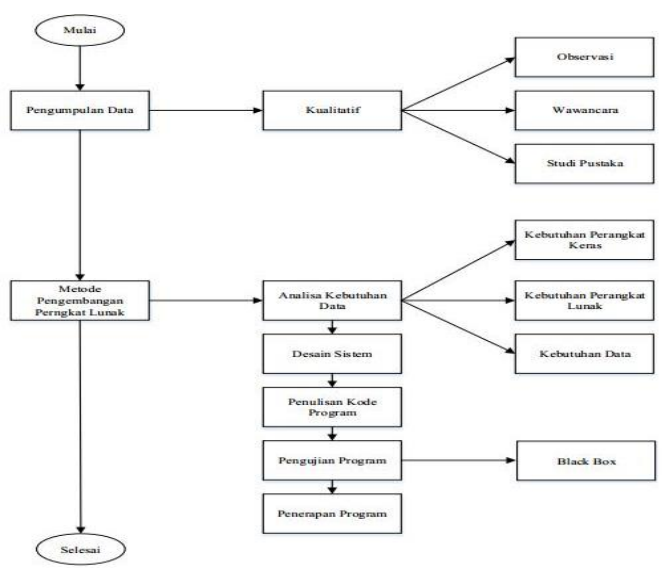

Gambar 2. Alur Metode Penelitian

Gambar diatas menggambarkan alur penelitian yang dimulai dari pengumpulan data dengan teknik wawancara, observasi dan studi pustaka. Metode pengembangan perangkat lunak yang digunakan yaitu waterfall yang terdiri dari tahap analisis, desain, pengkodean, pengujian dan penerapan.

Adapun metode yang digunakan dalam proses pengumpulan data dan pengembangan perangkat lunak adalah sebagai berikut:

\section{Metode pengumpulan data}

Metode pengumpulan data adalah metode yang digunakan untuk mengumpulkan data yang dibutuhkan dalam penelitian, metode yang digunakan adalah sebagai berikut:

a. Wawancara

Pada tahap ini penulis melakukan pengumpulan data melalui tanya jawab dan diskusi dengan ketua dan sekretaris penerimaan mahasiswa baru untuk mendapatkan informasi terkait dengan pengelolaan data calon mahasiswa baru. Dari pertanyaan yang diajukan oleh peneliti dan jawaban yang diberikan oleh ketua dan sekretaris penerimaan mahasiswa baru, dapat disimpulkan oleh penulis bahwa sistem pengelolaan data calon mahasiswa di STKIP Sumbawa saat ini masih menggunakan cara yang manual yaitu masih menggunakan buku besar dalam mencatat data calon mahasiswa dan formulir serta berkas persyaratan disimpan didalam lemari.

b. Observasi

Observasi dilakukan untuk mengumpulkan data dengan cara terjun/datang langsung ke lapangan atau lokasi, data yang dibutuhkan dalam penelitian skripsi ini.

c. Studi Pustaka

Peneliti yang dilakukan dengan cara membaca dan mempelajari buku-buku yang berhubungan dengan masalah yang akan diteliti sebagai tinjauan pustaka. Dalam penelitian ini, referensi yang digunakan berupa jurnal serta penelusuran melalui internet.

\section{Metode Pegembaga Peragkat Luak}

Penelitian ini menggunakan metode waterfall. Metode waterfall merupakan pengerjaan dari suatu sistem yang dilakukan secara berurutan atau secara linier. Disebut dengan waterfall karena tahap demi tahap yang dilalui harus menunggu tahap sebelumnya selesai.

Menurut (Pressman 2015) metode waterfall adalah metode klasik yang bersifat sistematis, berurutan dalam membangun software. Berikut ini gambaran tahapan proses pengerjaan dalam metode waterfall. Berikut adalah fase-fase dalam model waterfall berdasarkan referensi Pressman ${ }^{[5]}$ :

Berikut ini adalah model pengembangan waterfall :

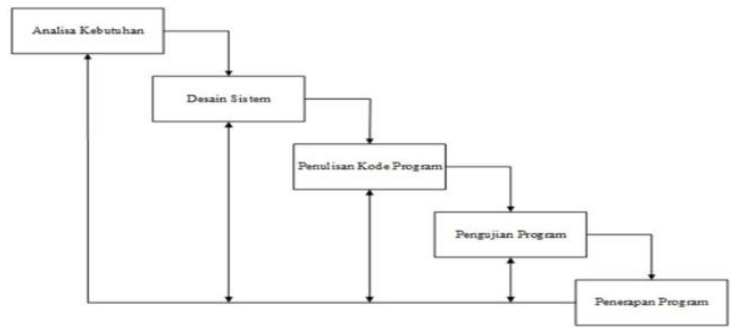

Gambar 3. Metode Waterfall

Berikut ini tahapan-tahapan dalam pengembangan perangkat lunak menggunakan model spiral:

\section{Analisa Kebutuhan}

Analisa kebutuhan ini merupakan tahap awal yang dilakukan oleh peneliti dalam mengembangkan sistem. Dalam analisa ini harus mendapatkan beberapa hal yang dianggap menunjang penelitian yang dilakukan, perangkat keras, perangkat lunak dan pengguna data. Dengan menggunakan analisa kebutuhan sistem maka dapat diketahui kebutuhan apa saja yang diperlukan dalam membangun sistem informasi Penerimaan Mahasiswa Baru Berbasis Web 
di Sekolah Tinggi Keguruan Ilmu Pendidikan Paracendekia Nahdlatul Wathan Sumbawa.

\section{Desain Sistem}

Setelah melakukan pengumpulan data dan mengetahui definisi aplikasi yang akan dibangun, maka selanjutnya adalah melakukan perancangan aplikasi yang akan dibangun. Perancangan ini meliputi perancangan sistem, perancangan basis data dan perancangan tampilan dari Sistem informasi sistem informasi Penerimaan Mahasiswa Baru Berbasis Web di Sekolah Tinggi Keguruan Ilmu Pendidikan Paracendekia Nahdlatul Wathan Sumbawa.

\section{Penulisan Kode Program}

Tahap ini merupakan proses puncak dalam pembuatan sistem, pembuatan sebuah sistem informasi yang berkesesuaian dengan apa yang telah dilakukan pada tahap perencanaan, analisa dan desain sistem. Penulis selanjutnya akan melakukan penulisan kode program dengan menggunakan bahasa pemrogramman $P H P$, Framework CodeIgneter, Ide Sublime Text, database $M y S Q L$ dan database server Xampp.

\section{Pengujian Program}

Tahap ini adalah tahap pengujian yang merupakan tahap pendukung yang artinya aplikasi yang telah dibuat dari hasil analisis masalah, tahap-tahap desain, penulisan kode program maka dilanjutkan ke dalam pengujian program. Sehingga akan dapat diketahui seperti apa hasil kinerja sistem tersebut. Kemudian dapat diketahui apakah sistem yang telah dibuat bejalan dengan baik sesuai dengan apa yang diharapkan. Pada langkah pengujian program ini, penulis akan melakukan pengujian dengan menggunakan metode black box dengan tujuan untuk menemukan kesalahan dari segi fungsionalitas perangkat lunak yang di uji sesuai dengan use case pada tahap sebelumnya.

\section{Penerapan Program}

Pada proses ini penulis melakukan pengoperasian sistem yang telah selesai dibuat pada STKIP Paracendekia NW Sumbawa untuk mengganti sistem yang sebelumnya menggunakan kertas dan disimpan dalam lemari, menjadi system yang terkomputerisasi dengan baik yang membantu pengelolaan data calon mahasiswa baru.

\section{HASIL DAN PEMBAHASAN}

Penerapan dari hasil metode waterfall yang telah di terapkan sampai dengan pengujian aplikasi pada penelitian ini dibagi atas pembahasan hasil perancangan dan pembangunan aplikasi E-commerce pada galeri UMKM Kabupaten Sumbawa berbasis $W E B$ yang telah di lakukan:

\section{Hasil Analisa Kebutuhan}

Adapun hasil analisis sebagai berikut :

\section{a) Analisis Sistem Yang Berjalan}

Berdasarkan hasil wawancara yang telah dilakukan oleh penulis kepada panitia penyelenggara Penerimaan Mahasisiwa Baru di STKIP Paracendekia NW Sumbawa, diketahui sistem yang sedang berjalan pada saat ini.:

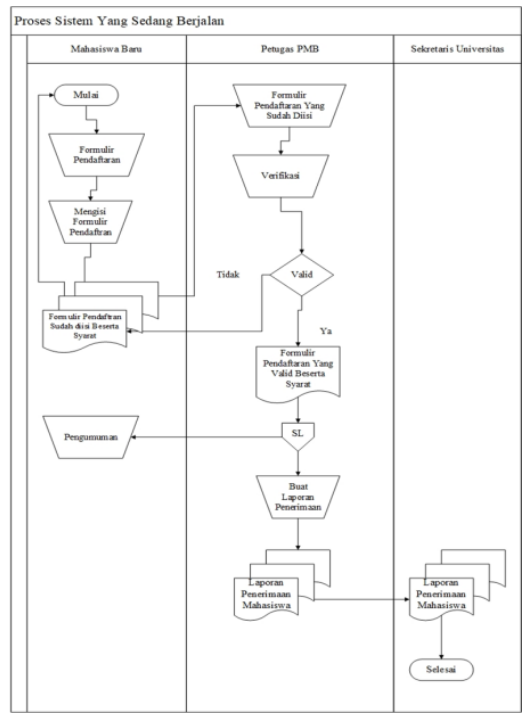

Gambar 4. Flowmap Proses Sedang Berjalan

Pada gambar Flowmap menjelaskan proses dimana data calon mahasiswa baru yang mendaftar hingga menumpuknya mengakibatkan penyimpanan data calon mahasiswa baru akan menjadi rumit. Rekapitulasi data calon mahasiswa baru yang harus di satukan dengan program studi yang di pilih. Calon mahasiswa baru juga harus ke kampus untuk melihat hasil pengumuman yang telah dikeluarkan oleh panitia penyelenggara. Sistem yang dilakakukan masih mengggunakan cara yang manual sehingga dalam proses pencarian data calon mahasiswa baru akan relatif lama.

\section{b) Rancangan Sistem Usulan}

Adapun sistem usulan yang akan di buat adalah sebagai berikut:

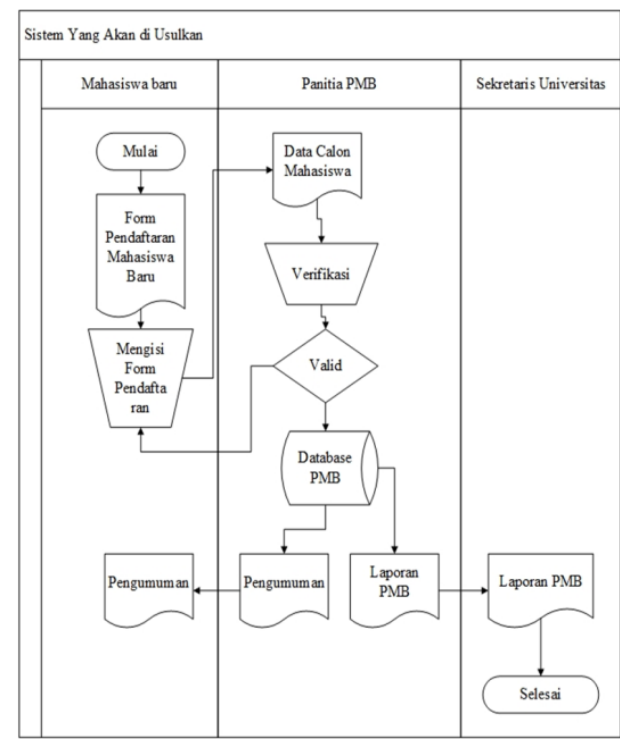

Gambar 5. Flowmap Sistem Usulan

Alur kerja dari sistem yang diusulakan pada STKIP Paracendekia NW Sumbawa adalah calon mahasiswa baru melakukan pengisisan formulir pendaftaran terlebih dahulu yang ada didalam web, kemudian data tersebut tersimpan dalam database. 
admin pmb selanjutnya mengelolah data calon mahasiswa yang telah mengisi formulir pendaftaran. Dari hasil pendaftaran calon mahasiswa baru petugas akan melakukan seleksi yang tersedia pada web admin, setelah selesai melakukan seleksi barulah data final yang nantinya akan di tampilkan pada menu pengumuman dan dapat di lihat oleh calon mahasiswa baru.

\section{Perancangan}

\section{a) Use case diagram untuk pendaftar}

Berikut adalah gambar use case diagram untuk pendaftar yang dimana gambar ini terdapat alur dari pendafttar dalammendaftar di web pmb.

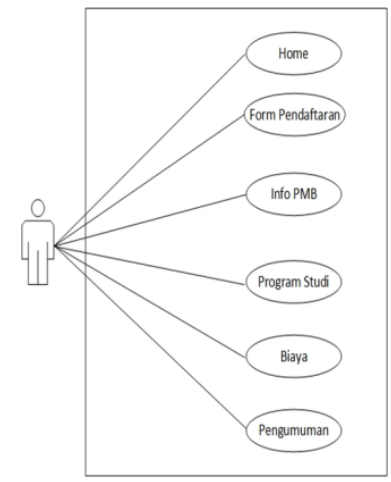

Gambar 6. Use case diagram untuk pendaftar

Berdasarkan Gambar diatas mesdiskripsikan bahwa pendaftar saat membuka web pmb akan langsung masuk ke menu utamayang berisikan menu home, form pendaftaran, info pmb, program studi, biaya dan pengumuman.

\section{b) Use case diagram untuk admin}

Berikut adalah gambar use case diagram untuk admin yang dimana dalam gambar ini terdapat alur dari admin dalam mengelolah data pmb.

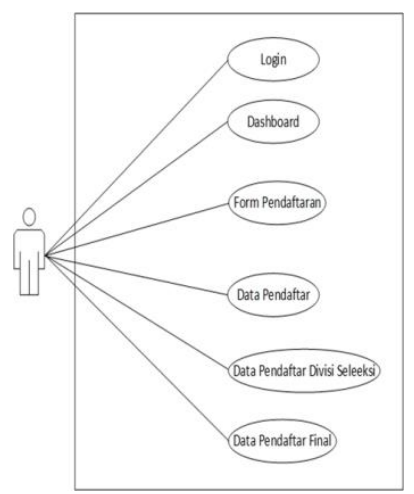

Gambar 7. Use Case Diagram Admin

Berdasarkan gambar diatas mendiskripsikan bahwa admin melakukan login terlebih dahulu agar bias mengakses menu utama halaman admin yaitu dashboard, form pendaftaran, data pendaftar, data pendaftar seleksi dan juga data pendaftar final.
Activity diagram atau diagram aktivitas adalah bentuk visual dari alur kerja yang berisi aktivitas dan tindakan, yang juga dapat berisi pilihan atau pengulangan.

\section{d) Squence Diagram}

Sequence diagram menggambarkan antar objek didalam dan di sekitar sistem (termasuk user, display dan sebagainya) berupa pesan yang digambarkan terhadapa waktu.

1. Sequence Diagram User

Dibawah ini merupakan sequens diagram User untuk pendaftar yang dimana gambar berikut adalah alur sistem bagaimana pendaftar saat membuat web pmb.

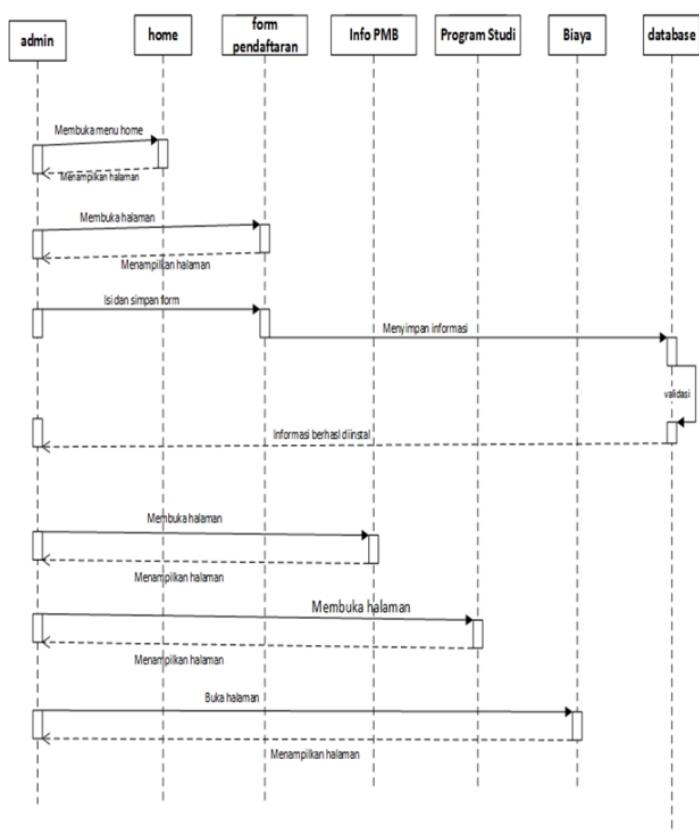

Gambar 8. Sequence Diagram User

2. Sequence Diagram Login

Gambar dibawah merupakan Sequence Diagram Login untuk admin yang diman gambar berikut adalah alur sistem bagaimana proses admin melakukan login.

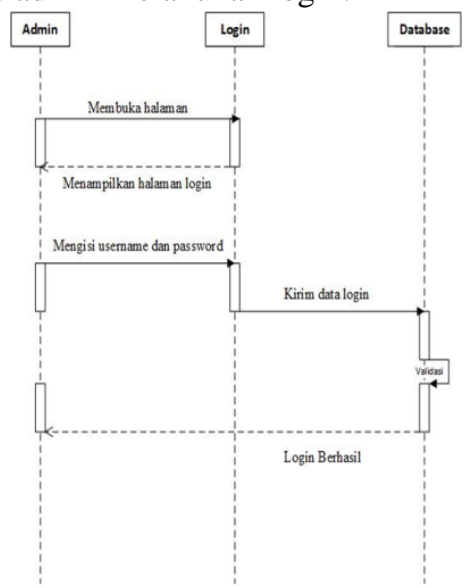

Gambar 9. Sequence Diagram Login 
3. Sequence Diagram Dashboard

Gambar dibawah merupakan Sequence Diagram Dashboard untuk admin yang dimana gambar berikut adalah alur sistem bagaimana proses admin dalam melakukan mengakses menu dashboard.

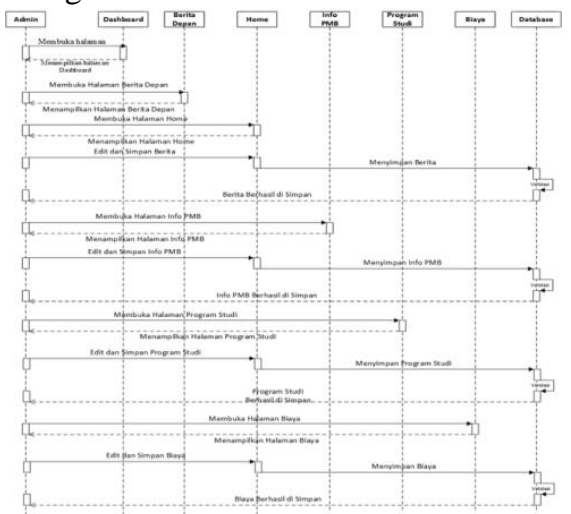

Gambar 10. Sequence Diagram Dashboard

4. Sequence Diagram Data Pendaftar Final

Gambar dibawah merupakan Sequence Diagram data pendaftar final untuk admin yang dimana gambar berikut adalah alur sistem bagaimana proses admin melihat data pendaftar final.

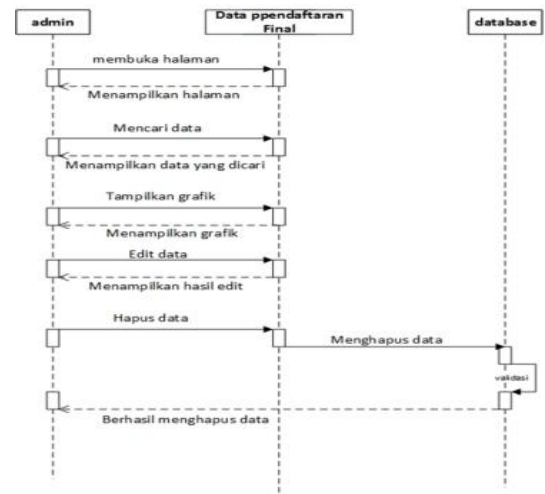

Gambar 11. Sequence Diagram Data Pendaftar Final

\section{Rancangan Database}

\section{a. Relasi Antar Tabel}

Relasi antar tabel adalah hubungan sebuah tabel dengan tabel lainnya. Sehingga tabel tidak berdiri sendiri, melainkan dapat dihubungkan antara satu dengan yang lainnya dan menjadi satu kesatuan.

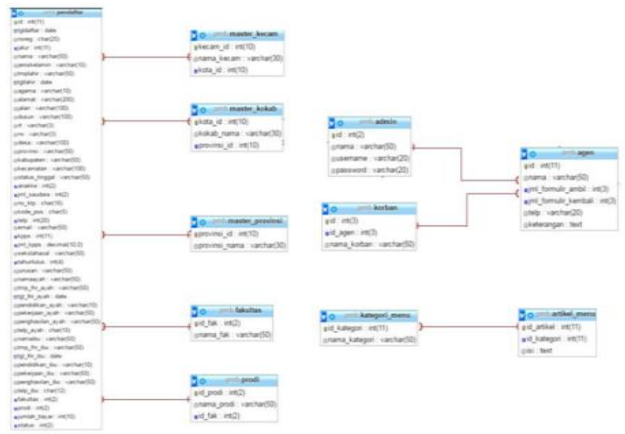

Gambar 12. Relasi Antar Tabel

\section{Rancangan rancangan tampilan}

Adapun rancangan tampilan yaitu terdiri dari rancangan tampilan utama, tampilan registrasi, tampilan login, halaman utama member, tampilan produk barang, tampilan keranjang, halman admin dan rancang tampilan menu-menu.

\section{a. Rancangan Tampilan Utama}

Berikut merupakan tampilan menu utama pada bagian user.

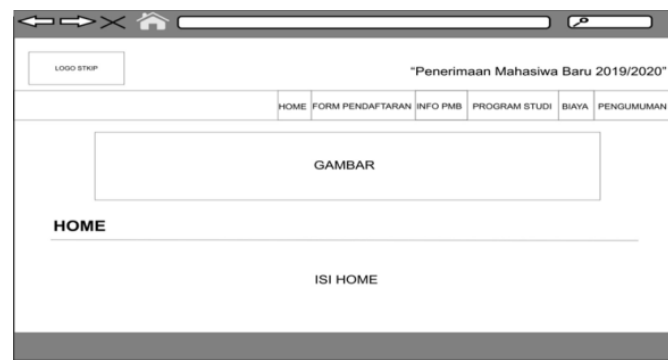

Gambar 13. Tampilan Utama

Rancangan tampilan menu home ini untuk menampilkan tentang STKIP Paracendekia NW Sumbawa dari sejarah di bangunnya, jumlah mahasiswa yang telah menempuh pendidikan dan prestasi yang telah di dapat selama ini.

\section{b. Rancangan Tampilan form pendaftaran}

Berikut merupakan tampilan dari form pendaftaran

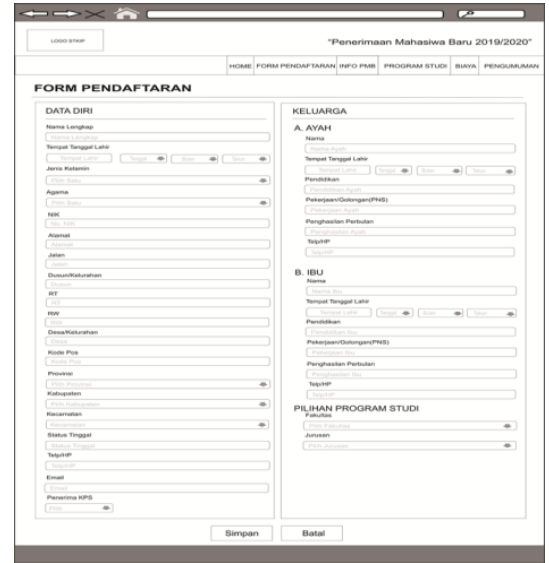

Gambar 14. Rancangan Form Pendaftaran

Rancangan form pendaftaran ini untuk menampilkan formulir yang harus diisi oleh calon mahasiswa baru dan nantinya data yang sudah diisi akan di seleksi oleh panitia penyelenggara.

\section{c. Rancangan login}

Berikut dari rancangan halaman login admin dari Sistem Informasi Penerimaan Mahasiswa Baru. 


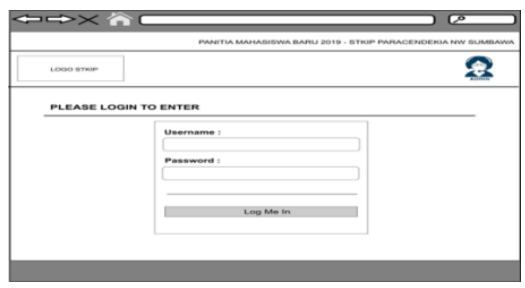

Gambar 15. Tampilan Login

Selanjutnya adalah halaman transaksi, pada halaman ini tercantum nama-nama product serta harga yang akan dibeli oleh member. Tetapi sebelum transaksi selesai, member harus mengisi beberapa form data untuk dijadikan laporan data jika barang ingin dikirim seperti nama penerima, alamat tujuan, provinsi tujuan, kode tujuan, kode pos dan nomor telepon. Jika selesai mengisi form, user dapat memilih menu simpan data da lanjutkan transaksi.

\section{d. Rancangan Tampilan Dashboard}

Berikut adalah rancangan dari halaman dashboard.

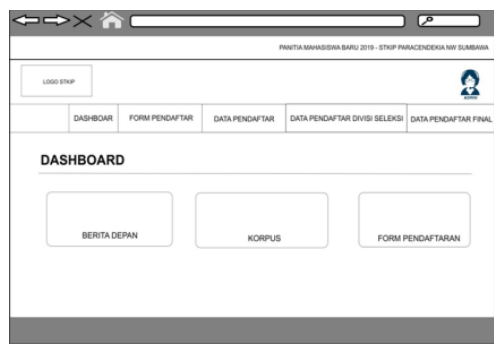

Gambar 16. Halaman Utama Admin

Pada halaman utama penjual atau admin terdapat beberapa pilihan menu yang dapat dilakukan oleh penjual seperti data password admin, data provinsi, data kategori barang, data barang, data promosi, data pelanggan, data pemesanan barang, data konfirmasi transfer, data laporan dan penjual dapat logout jika ingin keluar dari halaman.

\section{e. Rancangan Tampilan Data Pendaftar}

Berikut adalah rancangan tampilan data pendaftar.

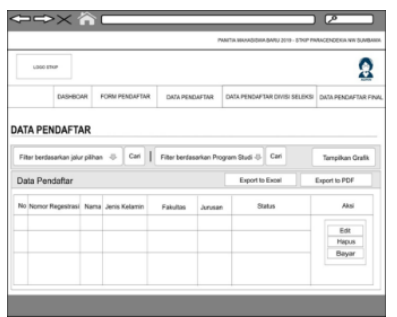

Gambar 17. Rancangan Tampilan Data Pendaftar

Pada rancangan tampilan data pendaftar ini menampilkan data pendaftar yang telah melakukan pengisian formulir yang ada pada web user dan di tampilan ini terdapat aksi yang dilakukan oleh admin seperti, edit, hapus dan bayar. Pada tampilan data pendaftar ini juga admi pmb dapat melakukan export to excel atau pdf untuk mencetak data pendaftar.

\section{f. Tampilan Data Pendaftar Final}

Berikut Merupakan Tampilan Dari Menu Data Pendaftar Final.

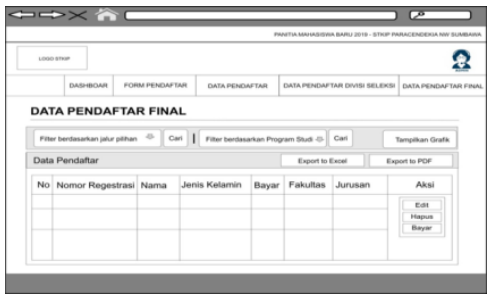

Gambar 18. Rancangan Tampilan data pendaftar final

Rancangan dari tampilan data pendaftar final ini menampilakn data calon mahasiswa baru yang telah melakukan pembayaran pendaftaran.

\section{Implementasi Program}

Setelah melakukan perancangan sistem antar muka, langkah selanjutnya adalah mengimplementasinya. Adapun tampilan dari sistem ini adalah sebagai berikut:

\section{a. Halaman Utama User}

Gambar berikut merupakan tampilan awal ketika mengakses web pmb.

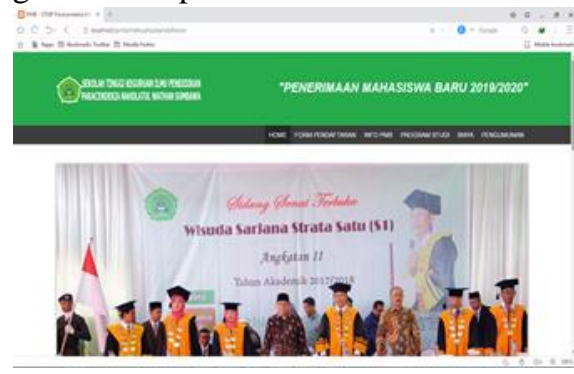

Gambar 19. Halaman User

Pada tampilan menu home ini merupakan tampilan utama pada saat user ataupun pendaftar membuka sistem. Menu home ini terdapat gambar yang menjadi gambaran dari STKIP Paracendekia NW Sumbawa. Adupun isi dari menu home ini yaitu tentang STKIP Paracendekia NW Sumbawa.

\section{b. Halaman Menu Form Pendaftaran}

Berikut merupakan tampilan form

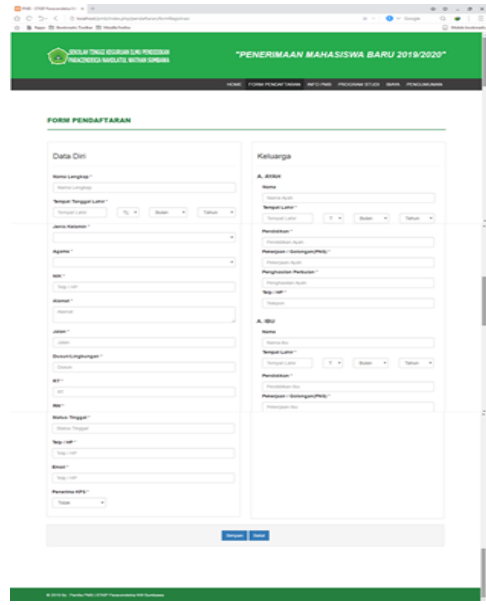

Gambar 20. Halaman Form Pendaftaran 
Pada tampilan menu form pendaftaran ini merupakan tampilan yang akan di isi oleh pendaftar untuk melakukan pendaftaran yang dimana pendaftar harus mengisi data dengan detail dan harus lengkap.

\section{c. Halaman Login}

Berikut adalah tampilan halaman login.

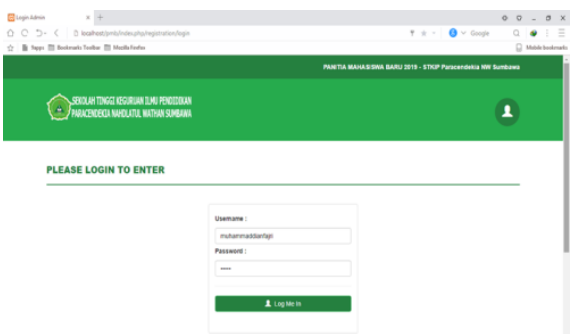

Gambar 21. Halaman Login

Halaman login adalah halaman yang pertama kali tampil ketika sistem pertama kali dibuka oleh admin pmb. Halaman ini terdapat dua form inputan yaitu username dan password. Untuk bisa masuk kedalam sistem, petugas (admin) harus mengisi form username dan password dengan benar sehingga admin pmb dapat mengelolah data-data para calon mahasiswa baru yang telah mendaftar.

\section{d.Halaman Dashboard}

Berikut adalah tampilan halaman dashboard dari Sistem Informasi Penerimaan Mahasiswa Baru.

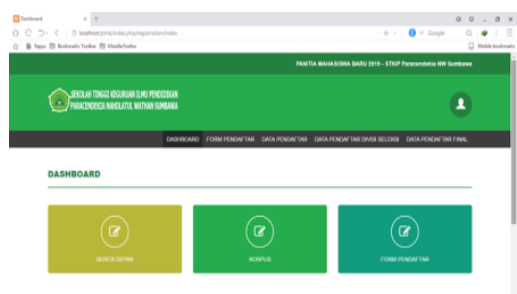

Gambar 22. Halaman Dashboard

Ketika admin pmb melakukan login dengan benar, maka tampilan yang pertama masuk yaitu tampilan dashboard. Pada halaman dashboard terdapat pilihan berita depan yang berfungsi untuk mengedit menu yang ada di halaman user. Korpus berfungsi untuk mengelolah data agen pmb dan menginput data calon mahasiswa baru yang mendaftar lewat agen tersebut. Form pendaftaran berfungsi untuk membantu calon mahasiswa dalam melakukan pengisian formulir.

\section{e. Halaman Menu Data Pendaftar Final}

Berikut adalah tampilan halaman menu data pendaftar final dari Sistem Informasi Penerimaan Mahasiswa Baru.

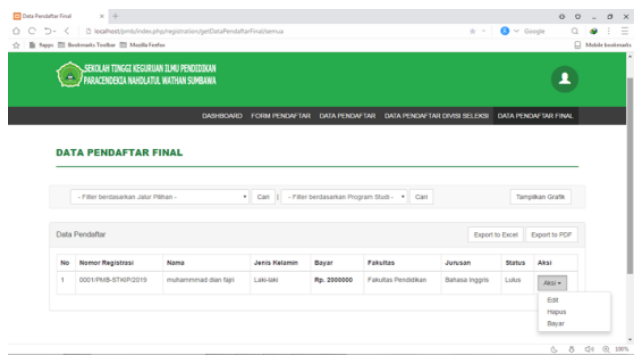

Gambar 23. Data Pendaftar

Pada halaman menu data pendaftar final ini merupakan data final dari pendaftar yang telah dinyatakan lulus. Pada halaman menu ini pun admin pmb dapat melakukan pencetakan data pendaftar dengan pilihan export to excel atau export to $p d f$.

\section{Pengujian Sistem}

Pada tahapan ini akan dilakukan pengujian system untuk memeriksa apakah suatu perangkat lunak yang dihasilkan sudah dapat dijalankan sesuai dengan standar tertentu. Pengujian sistem merupakan hal terpenting yang bertujuan untuk menemukan kesalahan-kesalahan atau kekurangan-kekurangan pada perangkat lunak yang diuji.

\section{a. Login Admin}

Tabel 1. Login Admin

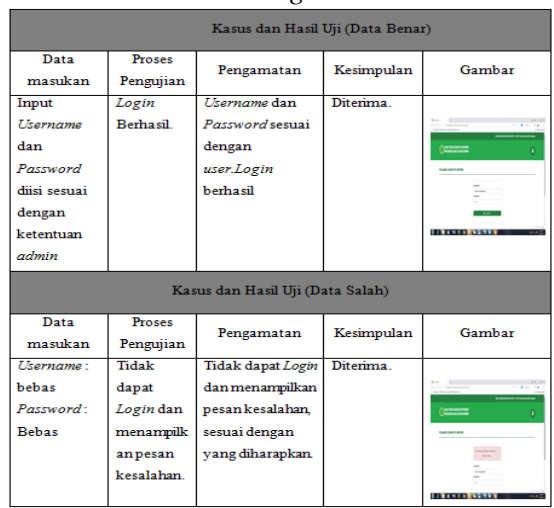

b. Form Pendaftar

Tabel 2. Form Pendaftar

\begin{tabular}{|c|c|c|c|c|}
\hline \multicolumn{5}{|c|}{ Kasus dan Hasil Uji (Data Benar) } \\
\hline \begin{tabular}{l}
\multicolumn{1}{c}{$\begin{array}{c}\text { Data } \\
\text { masukaan }\end{array}$} \\
Tombol \\
simpan $\mathrm{d} a n$ \\
batal.
\end{tabular} & \begin{tabular}{l}
\multicolumn{1}{c}{ Proses } \\
Pengujian \\
Pendaftar \\
memilih tombol \\
simpan, makka \\
data calon \\
mahasiswa akan \\
tersimpan ke \\
sistem. \\
Pendaftar \\
memilih tombol \\
batal maka data \\
Calon \\
mahasiswa \\
tidak akan \\
tersimpan
\end{tabular} & $\begin{array}{l}\text { Pengamatan } \\
\text { Tombol simpan } \\
\text { berfungsi untulk } \\
\text { menyimpan data } \\
\text { calon mahasis was } \\
\text { baru yang telah } \\
\text { mengisi form } \\
\text { pendaftar. } \\
\text { Tombol batal } \\
\text { berfungsi untulk } \\
\text { membatalkan } \\
\text { pendaftaran bagi } \\
\text { calon mahas is was } \\
\text { baru. }\end{array}$ & \begin{tabular}{|l} 
Kesimpulan \\
Diterima.
\end{tabular} & 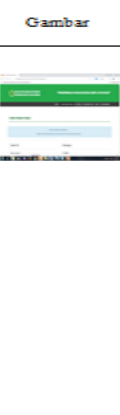 \\
\hline \multicolumn{5}{|c|}{ Kasus dan Hasil Uji (Data Salah) } \\
\hline $\begin{array}{c}\text { Data } \\
\text { masulkan }\end{array}$ & $\begin{array}{l}\text { Proses } \\
\text { Pengujian }\end{array}$ & Pengamatan & Resimpulan & Gambar \\
\hline $\begin{array}{l}\text { Tombol } \\
\text { simpan dan } \\
\text { batal }\end{array}$ & $\begin{array}{l}\text { Retika tombol } \\
\text { di klike tidak } \\
\text { berfungsi. }\end{array}$ & $\begin{array}{l}\text { Tombol yangdi } \\
\text { klik tidak } \\
\text { berfungsi. }\end{array}$ & Diterima & \\
\hline
\end{tabular}




\section{c. Data Pendaftar}

Table 3. Data Pendaftar

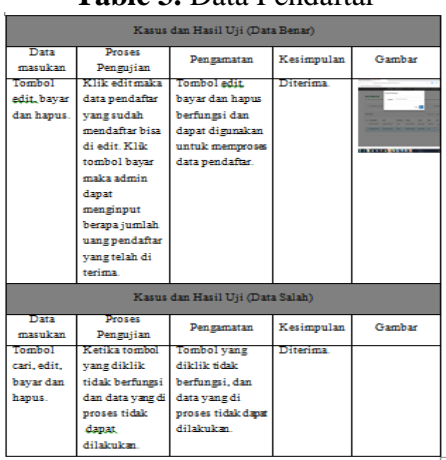

d. Data Pendaftar Divisi Seleksi

Tabel 4. Data Pendaftar Divisi Seleksi

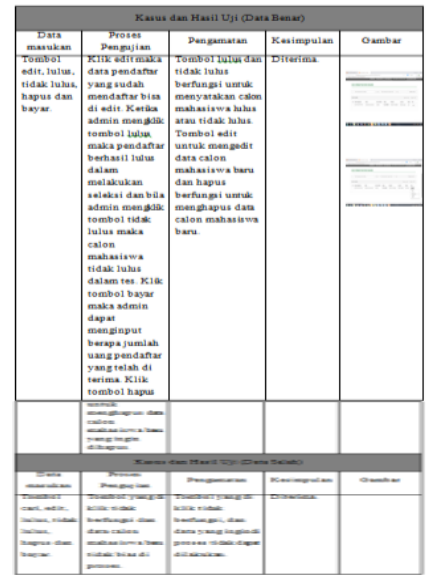

e. Data Pendaftar Final

Tabel 5. Data Pendaftar Final

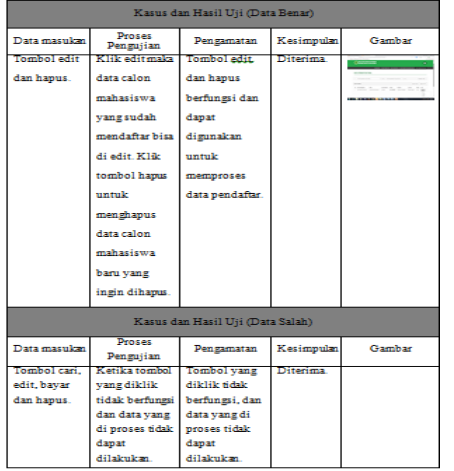

\section{Kesimpulan dan Saran}

\section{Kesimpulan}

Dari hasil analisis dan perancangan sistem yang telah dilakukan sebelumnya, maka penulis dapat mengambil kesimpulan bahwa Sistem Informasi Penerimaan Mahasiswa Baru berbasis web telah selesai dibangun dengan menggunakan metode penelitian kualitatif dan metode pengembangan perangkat lunak yaitu metode waterfall. Pembuatan sistem menggunakan bahasa pemrograman PHP dengan framework CodeIgniter, database MySql dan Css Bootstrap yang dapat digunakan oleh STKIP Paracendekia
NW Sumbawa untuk mempermudah calon mahasiswa baru dalam melakukan pendaftaran dan menerima pengumuman dengan mudah serta dapat membantu admin pmb dalam mengelolah data calon mahasiswa baru.

\section{Saran}

Dari hasil pembuatan Sistem Informasi Penerimaan Mahasiswa Baru di STKIP Paracendekia NW Sumbawa, penulis memberikan saran agar selanjutnya dilakukan pengembangan sistem seperti penambahan fitur-fitur seperti input foto dan juga input bukti pembayaran yang dilakukan melalui bank. Penambahan button cari pada menu pengumuman di halaman user agar mempermudah dalam mencari data calon mahasiswa baru yang telah lulus atau diterima.

\section{Daftar Pustaka}

[1] Ardhana, YM Kusuma, 2012. "Menyelesaikan Website 30 Juta!", Jakarta: Jasakom.

[2] Asropudin Pipin, 2013. "Kamus Teknologi Informasi". Bandung: Titian Ilmu.

[3] Booch, G. James, R. Ivar, J, 2005. The Unified Modeling Language User Guide Second Edition. United State: Addison Wesley Professional.

[4] Daqiqil, Ibnu. 2011. "Framework Codelgniter: Sebuah Panduan dan Best Practice".http://www.koder.web.id/Framewor k-codeigniter-sebuah-panduan-dan-bestpractice diakses 20 Maret 2019.

[5] Lestariningsih dkk. 2015. "Rancang Bangun $E$ Office Administrasi Surat Di Bagian Humas Universitas Stikubank Semarang". Jurnal Dinamika Informatika, Vol.7 No. 2, hlm. 2.

[6] Pressman, Roger S. 2015. Rekayasa Perangkat Lunak Pendekatan Praktisi. Yogyakarta: Penerbit Andi.

[7] Raharjo, Budi. 2011. "Membuat Database Menggunakan MySql". Bandung: Informatika.

[8] Satzinger, Jackson, Burd. 2012. "System Analisis and Design with the Unified Process". USA: Course Technology, Cengage Learning. 